\title{
BIOLOGICAL DECOLORIZATION OF REACTIVE AZO DYE BY ANAEROBIC/AEROBIC- SEQUENCING BATCH REACTOR SYSTEM
}

\author{
KOCYIGIT H. ${ }^{1, *}$ \\ UGURLU A. ${ }^{2}$
}

\author{
Department of Environmental Engineering \\ ${ }^{1}$ Aksaray University, Aksaray, Turkey \\ Department of Environmental Engineering \\ ${ }^{2}$ Hacettepe University, Beytepe, Ankara, Turkey
}

Received: 04/08/2014

Accepted: 21/01/2015

*to whom all correspondence should be addressed:

Available online: 05/03/2015 e-mail: hkocyigit@aksaray.edu.tr

\section{ABSTRACT}

This study aims to investigate the removal of a reactive azo dye (Reactive Red 198) in anaerobic/aerobic sequencing batch reactors (SBR). The total volume of the SBR system used in the study was $10 \mathrm{I}$. Sludge age was selected as 15 days. The color removal efficiencies varied between 76 to $98 \%$ with initial color concentrations of about 20 and $50 \mathrm{mg} \mathrm{l}^{-1}$. The effluent color concentration changed between 0.4-6.0 $\mathrm{mg} \mathrm{l}^{-1}$. The maximum dye removal efficiencies of the SBR system under $20 \mathrm{mg} \mathrm{l}^{-1}$ dye concentration with 16/4 hours anaerobic/aerobic phases respectively were \%98. The increase of anaerobic contact times had improved dye removal efficiency. The COD removal was also high during this period (81-94\%). The increase of organic loading rate from 500 to $1000 \mathrm{mg} \mathrm{COD} \mathrm{l}^{-1}$ day $^{-1}$ had improved the dye removal efficiency (from $88 \%$ to $96 \%$ ) but deteriorated the COD removal efficiency to $81 \%$ from $88 \%$ in SBR systems.

Keywords: RR198, Azo dye, Organic loading, Anaerobic/Aerobic SBR, Aromatic amines

\section{Introduction}

Azo dyes are widely used as colorants in textile industry. An important percentage of the dye (10-40\%) remains unfixed in its hydrolyzed form in the washing liquors (García-Montaño et al., 2006). The type of dye stuff, application technique and the depth of shade required affect the amount of dye lost (Pearce et al., 2003). Azo dyes can also be used in the food, pharmaceutical, paper and printing, leather and cosmetics industries. The effluents from these industries contain azo dyes. Azo dyes make up approximately $30 \%$ of the dyes used. As well as being toxic to aquatic life the dyes in the wastewater and their breakdown products are carcinogenic and mutagenic to humans (Panswad and Luangdilok, 2000; Shaw et al., 2002; Weisburger, 2002; Pinheiro et al., 2004). It is also aesthetically undesirable and negatively affects water transparency and gas solubility in water bodies (Khosa et al., 2013). Stringent legislations controlling the use of azo-dyes have been put into force in many countries.

Due to their stability and to their xenobiotic nature, reactive azo dyes are not totally degraded by conventional wastewater treatment processes. Therefore several physical, chemical and biological techniques are applied. Physical and chemical treatments may improve color removal efficiency but they are very expensive to be applied (Sirianuntapiboon et al., 2006; Patel and Vashi, 2013). Treatment of azo dyes by conventional aerobic

Kocyigit H. and Ugurlu A. (2015), Biological decolorization of reactive azo dye by anaerobic/aerobic-sequencing batch reactor system, Global NEST Journal, 17(1), 210-219. 
biological wastewater methods is difficult. There is no single treatment method for the wastewaters containing azo dyes. Azo dyes strongly resist aerobic digestion but are readily decolorized by anaerobic biological treatment (Isık and Sponza, 2004; Ong et al., 2005; Liu et al., 2013). The biodegradation of azo dyes proceeds in two stages. Therefore, biological treatment of azo dyes requires sequencing anaerobic and aerobic conditions. In the first stage, azo dye decolourisation by anaerobic biodegradation results in cleavage of the azo linkages and involves transfer of four-electrons. Aerobic conditions are required for bacterial decomposition of aromatic amines. The decolourisation rates are extremely dependent on type of dye, where azo dyes present highest rates of decolourisation whereas anthraquinone and phthalocyanine dyes are rather calcitrant (Dos Santos et al., 2007). It is reported that anaerobic/aerobic sequencing batch reactors treat compounds which are difficult to degrade such as azo dyes (Panswad et al., 2001; Lourenço et al., 2006; Amaral et al., 2014)

The aim of this study was to investigate degradation of Reactive Red 198, an azo dye, in an anaerobic/aerobic sequencing batch reactor (SBR). Sequencing batch reactors which are widely used for biological nutrient removal will also provide the necessary sequential anaerobic and aerobic phases for color removal.

\section{Methods and Materials}

The azo dye, Reactive Red 198, was chosen as a model compound which the chemical structure is shown in Fig.1. since it represents a large class of dyes used in the textile industry.

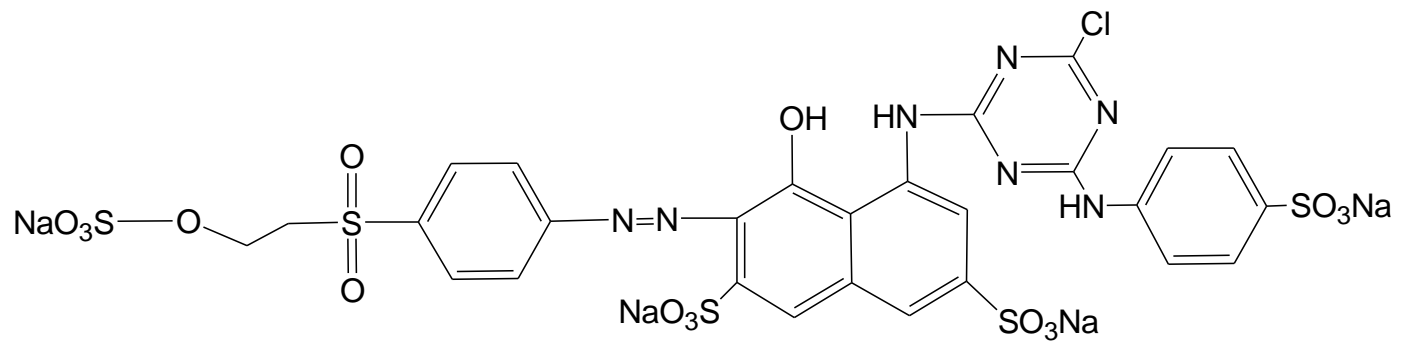

Figure 1. Chemical structure of Reactive Red 198

A laboratory scale sequencing batch reactor was made of up acrylic plastic with a diameter of $20 \mathrm{~cm}$ and a height of $50 \mathrm{~cm}$. The active total volume of the SBR system was $10 \mathrm{I}$. The volumetric exchange ratio was $25 \%$. Therefore, about $2.5 \mathrm{I}$ of settled content of the reactor was removed and then displaced with fresh simulated colored wastewater. The SBR system was operated in anaerobic/anoxic feeding, mixing, mixing and aeration and settling periods. The system was filled by the use of a peristaltic pump. The contents were mixed with stainless steel mechanical mixer with two paddles and air was supplied by an aquarium type pump. Operation of the peristaltic pump (filling), mixer, air flow (aeration) and solenoid valve (decanting) were controlled by means of a timer. The operation sequence is shown in Fig. 2 . The reactor was run at room temperature. During feeding, aeration was not applied but mixing was on. The system was mixed during the anaerobic/anoxic phase and aeration was started in the succeeding aerobic phase. The system was continuously aerated and mixed during this period. After settling, the treated wastewater was decanted by the use of a solenoid valve.

The system was first inoculated with activated sludge taken from a sequencing batch reactor treating domestic wastewater. It was acclimatized to synthetic wastewater of $400 \mathrm{mg} \mathrm{l}^{-1} \mathrm{COD}$ (glucose). The solid retention time (SRT) was chaged between 10 to 15 days during the operation. The desired SRT was maintained by withdrawal of certain amount of mixed liquor suspended solids (MLSS) at the end of the reaction period once a day. It is known that both VFA and glucose support azo dye reduction (Razo-Flores et al., 1997; Baeta et al., 2013). Therefore, glucose, starch and Na-Acetate were added as main carbon sources for co-metabolism. Table 1 
shows the composition of the synthetic wastewater, while operational conditions in the study are depicted in Table 2.

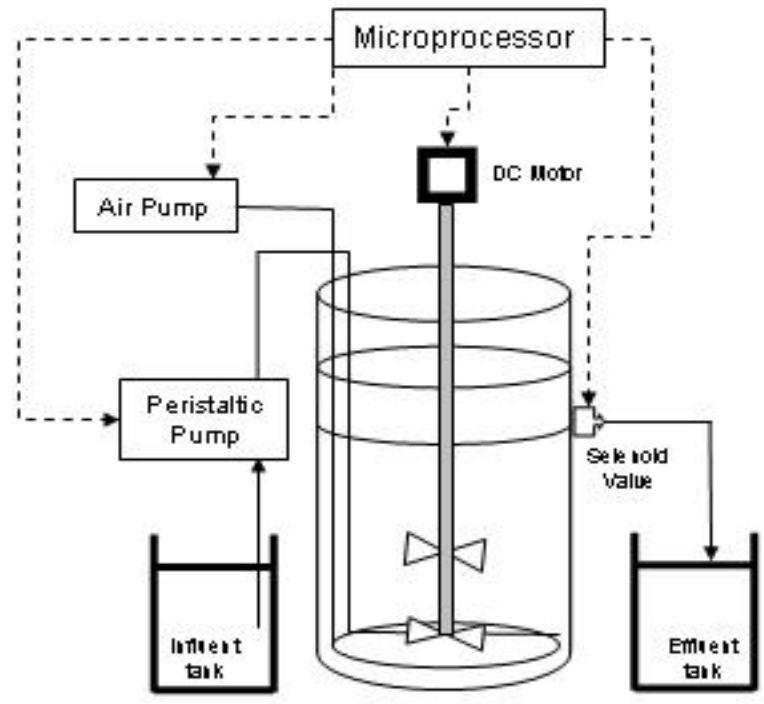

Figure 2. The SBR system reactor

Glucose, starch and acetate were added to the synthetic wastewater as a carbon source to attain $500 \mathrm{mg} \mathrm{l}^{-1}$ COD in Set 1-5 and $1000 \mathrm{mg} \mathrm{l}^{-1}$ in the Set 6. $\mathrm{NH}_{4} \mathrm{Cl}$ and urea was also added as nitrogen source and $\mathrm{KH}_{2} \mathrm{PO}_{4}$ as phosphate source (COD:N:P of 100:8:2) to support azo dye reduction besides the mineral salts medium. The Reactive Red (RR) 198 concentration was $20 \mathrm{mg} \mathrm{l}^{-1}$ in Sets 1-4 and increased to $50 \mathrm{mg} \mathrm{l}^{-1}$ in the Sets 5 and 6. MLSS concentrations changed between $3000 \mathrm{mg} \mathrm{l}^{-1}$ to $1876 \mathrm{mg} \mathrm{l}^{-1}$ with a MLVSS/MLSS ratio of 64 to $86 \%$.

Table 1 Composition of the synthetic wastewater

\begin{tabular}{cc}
\hline Constituents & Concentration (mg $^{-1}$ ) \\
\hline Glucose & 250 (as COD) \\
\hline Starch & 120 (as COD) \\
\hline Na-Acetate & 80 (as COD) \\
\hline Yeast Extract & 40 (as COD) \\
\hline $\mathrm{NH}_{4} \mathrm{Cl}$ & 20 (as N) \\
\hline Urea & 20 (as N) 10 (as COD) \\
\hline $\mathrm{KH}_{2} \mathrm{PO}_{4}$ & 10 (as P) \\
\hline $\mathrm{NaHCO}_{3}$ & 300 (as CaCO \\
\hline
\end{tabular}

The performance of the SBR system was evaluated in terms of COD and RR 198 removal efficiencies. The dye concentration and COD were periodically measured, while change of $\mathrm{pH}$ and ORP were measured hourly. RR 
198 was measured by UV-vis spectrophotometer (Dr. Lange Cadas 200) at a wavelength of $508 \mathrm{~nm}$ which is the maximum absorbance spectra obtained for this azo dye. The effect of anaerobic/aerobic periods on decolorisation of RR198 was investigated. For this purpose anaerobic period was chaged between 16 to $5 \mathrm{~h}$, and aerobic period was changed between 2-10 h (Table 2).

Table 2 Operational conditions in the study.

\begin{tabular}{cccccccc}
\multirow{2}{*}{ SET } & COD $\left(\mathbf{m g ~ l}^{-1}\right)$ & RR198 $\left(\mathbf{m g ~ l}^{-1}\right)$ & Cycle time $(\mathbf{h})$ & \multicolumn{4}{c}{ Phase Durations $(\mathbf{h})$} \\
\cline { 5 - 8 } & & & & Fill & Anaerobic & Aerobic & Settling \\
\hline SET 1 & 501 & 20.0 & 24 & 1 & 10 & 10 & 3 \\
\hline SET 2 & 502 & 20.1 & 12 & 1 & 5 & 5 & 1 \\
\hline SET 3 & 501 & 20.0 & 12 & 1 & 8 & 2 & 3 \\
\hline SET 4 & 499 & 20.1 & 24 & 1 & 16 & 4 & 3 \\
\hline SET 5 & 504 & 50.2 & 24 & 1 & 16 & 4 & 3 \\
\hline SET 6 & 1010 & 50.2 & 24 & 1 & 16 & 4 & 3
\end{tabular}

Mixed liquor volatile suspended solids (MLVSS) and mixed liquor suspended solids (MLSS) concentrations and sludge volume index (SVI) in the reactor were monitored regularly. MLVSS, MLSS and SVI measurements were carried out in accordance with the Standard Methods (APHA, AWWA, WEF, 2005). pH values were measured by $\mathrm{pH}$ electrode WTW SenTix 41, Oxidation Reduction Potential (ORP) was monitored by WTW Electrode SenTix ORP probe connected to a pH meter. The dissolved oxygen (DO) concentrations were measured by WTW Oxi 330/Set. Chemical Oxidation Demand (COD) was quantified by means of specific chemical analysis kits numbered LCK 614-314 (Dr. Lange), using spectrometric methods.

\section{Results and Discussion}

The reactor performance was tested under 6 different operational conditions at room temperature $\left(22 \pm 3^{\circ} \mathrm{C}\right)$ to study the effect of anaerobic and aerobic phase durations on COD and color removal. Table 3 summarizes the SBR performance obtained in the study.

Table 3 Operational conditions and performance achieved in the study

\begin{tabular}{cllllllll}
\hline \multirow{2}{*}{ SET } & \multicolumn{2}{c}{ Influent $\left(\mathrm{mg} \mathrm{l}^{-1}\right)$} & \multicolumn{2}{c}{ Effluent $\left(\mathrm{mg} \mathrm{l}^{-1}\right)$} & \multicolumn{2}{c}{ Removal (\%) } & \multicolumn{2}{c}{ Anaerobic Phase } \\
\cline { 2 - 9 } & COD & Color & COD & Color & COD & Color & ORP (mV) & pH \\
\hline SET 1 & 501 & 20.0 & 28.7 & 1.22 & 94 & 94 & -115 & 7.9 \\
\hline SET 2 & 502 & 20.1 & 47.0 & 4.90 & 91 & 76 & -97.4 & 8.0 \\
\hline SET 3 & 501 & 20.0 & 97.1 & 3.67 & 81 & 82 & -120 & 7.9 \\
\hline SET 4 & 499 & 20.1 & 60.9 & 0.40 & 88 & 98 & -445 & 8.0 \\
\hline SET 5 & 504 & 50.2 & 62.6 & 6.03 & 88 & 88 & -444 & 7.9 \\
\hline SET 6 & 1010 & 50.2 & 196 & 1.90 & 81 & 96 & -447 & 8.0 \\
\hline
\end{tabular}

It is known that azo dyes are reduced under anaerobic conditions. Color removal efficiencies in Set 1-4 varied between 76 to $98 \%$ with an initial color concentration of about $20 \mathrm{mg} \mathrm{l}^{-1}$ (Fig. 3). The effluent color concentration changed between 0.4-4.9 mg l-1 The SBR system was operated 1 cycle/day in Set 1 and Set 4, 2 cycles/day in Set 2 and Set 3, the total reaction time (anaerobic/aerobic) being 20 and $10 \mathrm{~h}$ respectively. Since 
oxygen is a more effective electron acceptor than azo dye, low decolorisation rates can be expected in the aerobic phase (Dos Santos et al., 2007; Cirik et al., 2013). However, aerobic conditions are required for degradation of aromatic amines produced in the anaerobic phase. It was observed that color removal took place almost entirely in the anaerobic phase. As can be seen from the Figure 4, dyes were predominantly removed in the first 4 hours of the anaerobic phase.

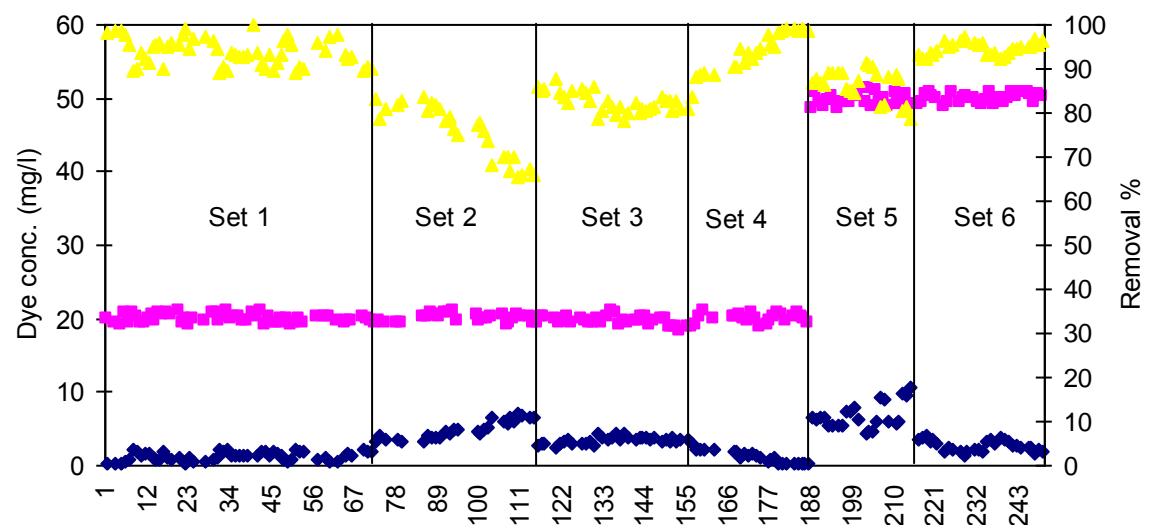

\begin{tabular}{|l|l}
\hline Dye inf. $\bullet$ Dye eff. $\triangle$ Removal \% & Time (day)
\end{tabular}

Figure 3. Variation of dye concentration and \% color removal during the different sets of the operation

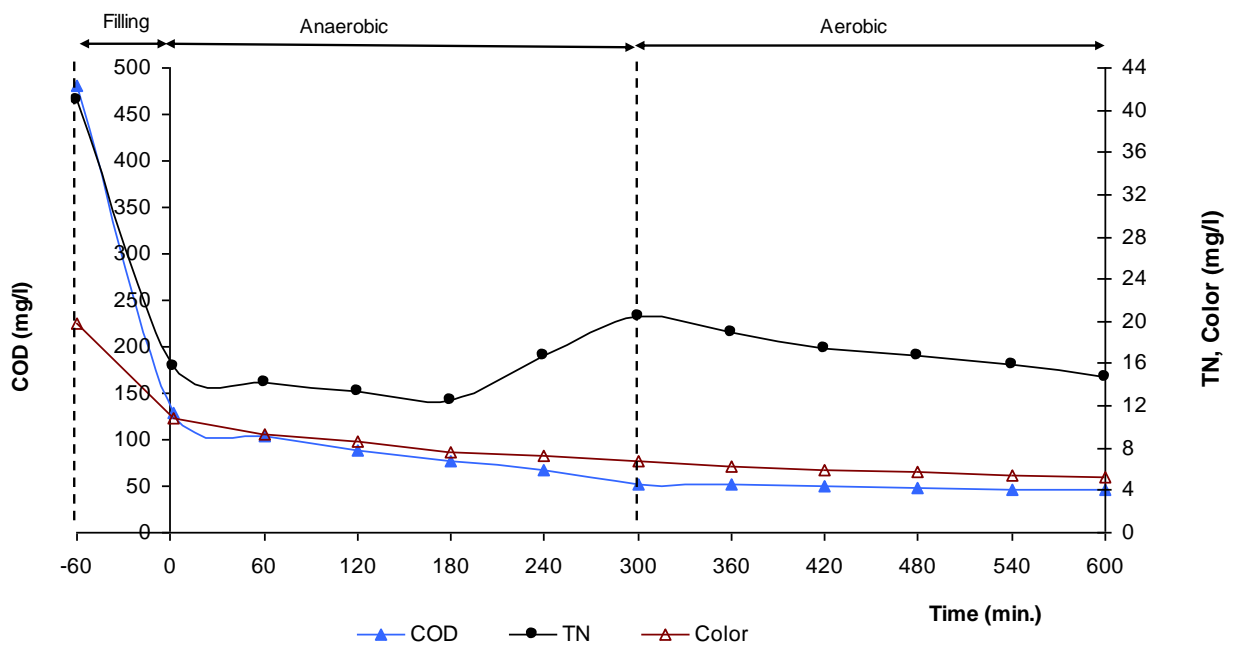

Figure 4. Color, TN and COD values measured during the $12 \mathrm{~h}$ reactor a cycle

Higher influent concentrations of azo dyes require longer reaction periods. Therefore, different anaerobic phase durations were applied to optimize color removal in the system. In Set 5 and Set 6 where dye concentrations were about $50 \mathrm{mg} \mathrm{l}^{-1}$, longer anaerobic periods $(16 \mathrm{~h})$ were applied in order to get higher color removal. Increasing anaerobic phase duration had positive effect on system performance; however, the difference in RR 198 removal efficiencies in both sets was negligible.

The color removal achieved in Set 1 was approximately $94 \%$ with 1 cycle/day and with 10/10 h anaerobic/aerobic phase durations. By increasing the cycle period to 2 cycles/day and thus decreasing the reaction periods by half in Set 2 , a significant decrease in color removal was observed (76\%). This was mainly due to increase in the color and COD load. Then, the anaerobic phase duration was increased to $8 \mathrm{~h}$ with a 
decreased aerobic phase duration of $2 \mathrm{~h}$ in Set 3. Under these conditions, it was found that the RR 198 removal efficiency in Set 2 and Set 3 was almost similar. Increase in the anaerobic phase duration from 5 to $8 \mathrm{~h}$ resulted in increase in color removal from 76 to $82 \%$ in Set 2 and Set 3, respectively. Increasing anaerobic phase duration had positive effect on color removal. However, the effect was not significant. Similar results were obtained in the previous works (Lourenço et al., 2001; Panswad et al., 2001; Pasukphun and Vinitnantharat, 2003). In contrast, COD removal decreased in Set 3 . Increasing the duration of anaerobic phase resulted in increase in the effluent COD concentration to $97.1 \mathrm{mg} \mathrm{l}^{-1}$ in Set 2 which was $47.0 \mathrm{mg} \mathrm{l}^{-1}$ in Set 3.

The cycle time was increased to $24 \mathrm{~h}$ in Set 4 (accompanyied by a decreased organic load). Slightly higher color removals (8\%) were obtained in Set 1 than Set 4, when anaerobic phase was $16 \mathrm{~h}$ in Set 4 . Increasing the anaerobic phase duration did not affect the color removal significantly. The COD concentration improved in Set 4, however, it was $6 \%$ lower than Set 1 . Increase in the anaerobic phase duration resulted in increase in the effluent COD concentration from 28.7 to $60.9 \mathrm{mg} \mathrm{l}^{-1}$ in Set 1 and Set 4, respectively. It was not possible to draw a conclusion on the effect of anaerobic/aerobic phase durations on color removal. It was observed that increase in the anaerobic phase from 5 to $10 \mathrm{~h}$ resulted in increase in color removal. However, in Set 4 the cycle/day ratio was 1 . The anaerobic reaction duration was doubled in this set. But the total volume exchanged was reduced by half (HRT was doubled). This resulted in higher color removal which was $22 \%$ and $16 \%$ higher than that of in Set 2 and Set 3 respectively. The Figure 5 shows that the color removal increases with increasing anaerobic contact time.

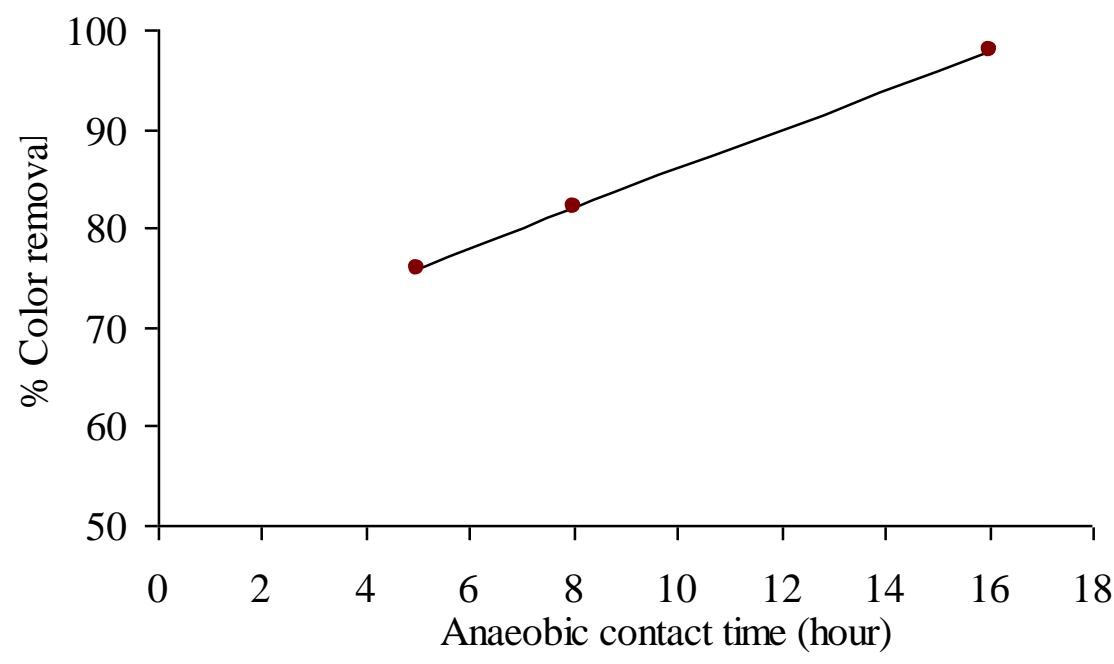

Figure 5. Color removal efficiencies at different anaerobic phase

Increasing the dye concentration to $50 \mathrm{mg} \mathrm{l}^{-1}$ in Set 5 under the same operational conditions with Set 4 resulted in increase in the effluent dye concentration to $6.03 \mathrm{mg} \mathrm{l}^{-1}$ from $1.9 \mathrm{mg} \mathrm{l}^{-1}$, i.e. color removal decreased by $10 \%$ (see Fig. 3). However, the increase in the dye concentration did not deteriorate the COD removal which may indicate that this dye concentration was not toxic to bacteria. COD removal efficiency remained similar (88\%). Figure 6 summarizes the COD removal efficiency under different operational conditions during the study. It was observed that the anaerobic time required to remove the color increased at higher dye concentrations. In order to observe the effect of carbon source concentration on color removal, the COD concentration was doubled in Set 6 . It was observed that higher COD concentration ( $C$ source) enhanced color removal and thus higher color removals were obtained. This increase was about $8 \%$. Previous studies 
investigating the effect of organic loading rate on azo dye removal show similar increased color removal (Talarposhti et al, 2001; Ong et al., 2005; Wijetunga et al., 2010).

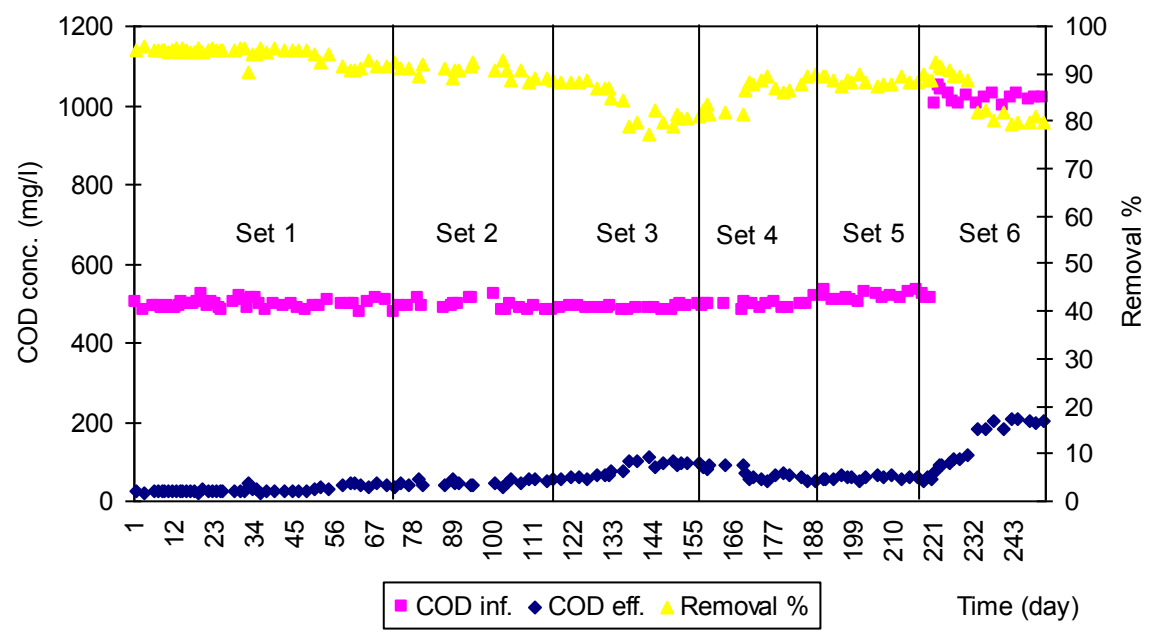

Figure 6. Variation of COD concentration and \% COD removal during the different sets of the operation

Increasing COD concentration to $1000 \mathrm{mg} \mathrm{l}^{-1}$ in Set 6 under the same operational conditions with Set 5 resulted in improved decolourisation. Effluent RR 198 concentration decreased to $1.9 \mathrm{mg} \mathrm{l}^{-1}$ from $6.03 \mathrm{mg} \mathrm{l}^{-1}$. As can be expected increase in the organic load resulted in increase in electron donors in the environment. Therefore, the azo dyes as electron acceptor are reduced. Increase in the organic load has positive effect on color removal. The aromatic amines detected at the end of the anaerobic stage of the sysyem were; $\mathrm{N}$ methylalanine, aniline, O-toluidine, 4-Chloroaniline, 4 amino phenol and aminobiphenyl. However, at the end of the aerobic phase some of the amines detected in the beginning of the phase disappeared leaving the aromatic amines detected at the end of the aerobic stage as aniline, O-toluidine, 4 amino phenol and 4aminobiphenyl. This shows that the aromatic amins produced in the anaerobic phase were demineralised in the aerobic phase.

The hourly changes of COD, total nitrogen (TN), color and pH were investigated in all sets. The result obtained in Set 2 was depicted in Figure 4. As can be seen from the figures, the color removal was achieved in the anaerobic phase and anaerobic/anoxic fill phase. The color removal in the aerobic phase was negligible. Adsorption of dye on bacterial cells was also observed, however, the contribution on total color removal was low ( $<10 \%$ ) (data was not shown). COD removal also mainly occurred in the anaerobic phase. A small amount of COD was also removed in the following aerobic phase. Total nitrogen concentrations also varied during individual cycles. The concentration of TN increased in the anaerobic phase. This increase started 3 hours after the initiation of the anaerobic phase. The TN concentration decreased under oxic conditions. The TN concentration decreased to about $15 \mathrm{mg} \mathrm{TN} \mathrm{I}^{-1}$ at the end of the aerobic phase where it was about $20 \mathrm{mg} \mathrm{l}^{-1}$ at the beginning of the phase.

The variation of oxidation reduction potential during a cycle was also monitored. The ORP dropped to -100 $\mathrm{mV}$ in the anaerobic phase and it increased during the anaerobic phase and reached to $+150 \mathrm{mV}$ at the end of the $5^{\text {th }}$ hour of the oxic reaction period. Under anaerobic conditions a low redox potential (ORP $<-50 \mathrm{mV}$ ) was achieved during the study which was reported as necessary for an efficient decolorisation of dyes (Bromley-Challenor et al., 2000; Albuquerque et al., 2005; Van der Zee and Villaverde, 2005; Dos Santos et al., 2007). These studies suggest very low ORP values are necessary for the anaerobic reduction of azo bonds (around $-400 \mathrm{mV}$ for reactive dye decolorisation). A considerable drop in ORP was observed during the anaerobic period. The redox potential in Sets 1,2 and 3 fluctuated between the values of $-98 \mathrm{mV}$ and $-120 \mathrm{mV}$ 
during the anaerobic phase. However, increasing the duration of anaerobic phase resulted in lower ORP values $(<-444 \mathrm{mV})$ in Sets 4, 5 and 6. Fig. 7 shows variation of ORP values during anaerobic and aerobic phase in 12 $\mathrm{h}$ cycle. This showed that reduction potential in the anaerobic phase so cleavage of azo bond which was below $-50 \mathrm{mV}$.

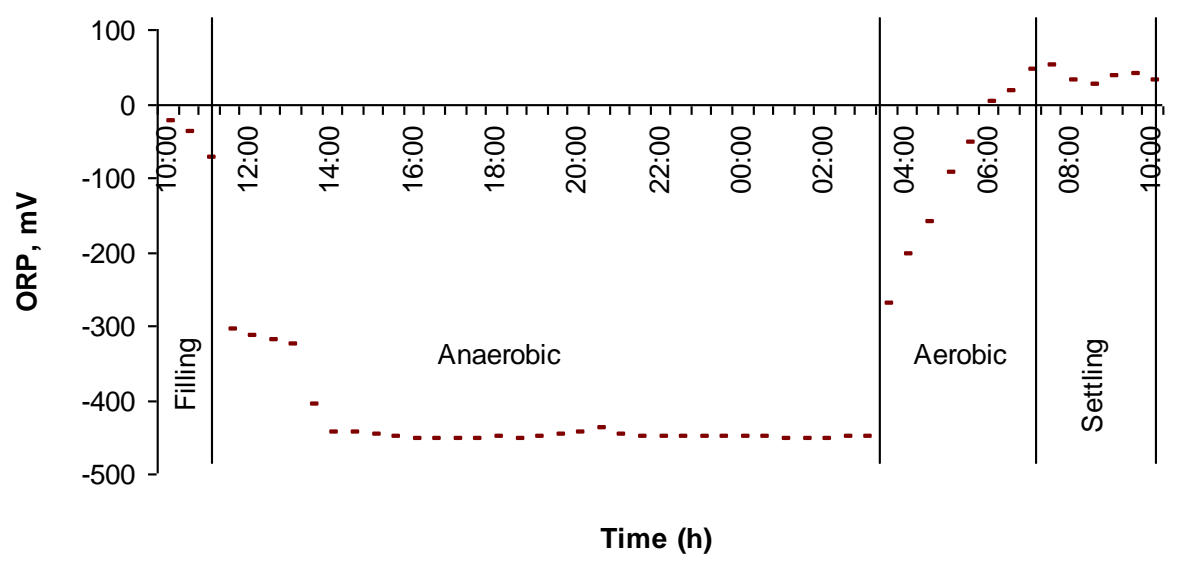

Figure 7. ORP values measured during the reactor a cycle

Biological reduction of the azo bond can result in an increase in the $\mathrm{pH}$ due to the formation of aromatic amine metabolites, which are more basic than the original azo-compound. The change in $\mathrm{pH}$ was also remarkable throughout a cycle (Fig. 8).

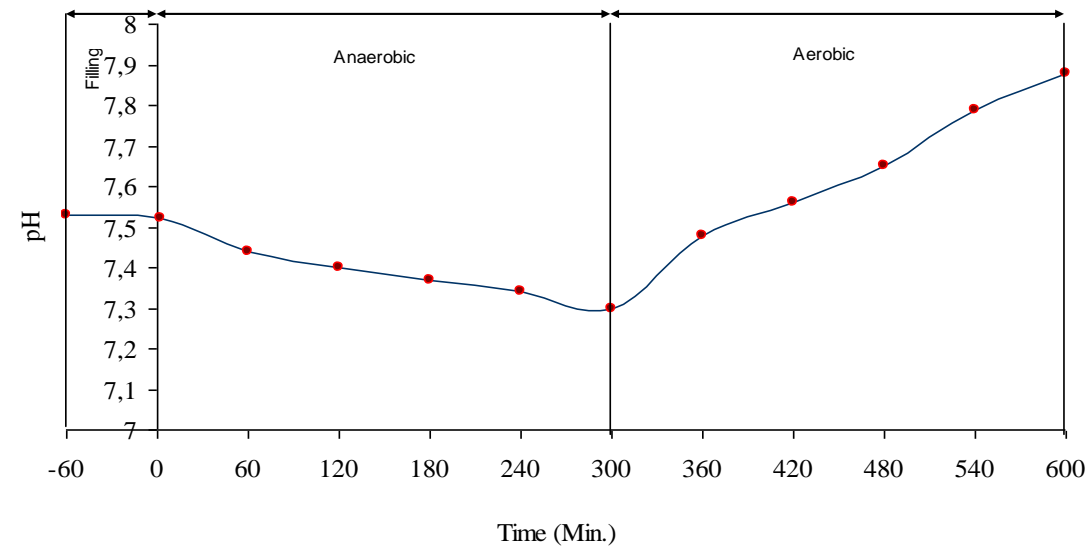

Figure 8. $\mathrm{pH}$ values measured during the $12 \mathrm{~h}$ reactor a cycle

$\mathrm{pH}$ value of the influent synthetic wastewater was around $7.5 \mathrm{mV}$, with an observed slight decrease during the anaerobic phase $(7.3 \mathrm{mV})$. Intermediate products generated by the degradation of organic matter yields fatty acids. As a result, a decrease in $\mathrm{pH}$ values was observed in the anaerobic phase. In the succeeding aerobic phase fatty acids were removed and this resulted in increase in $\mathrm{pH}$. The $\mathrm{pH}$ increased consistently in the aerobic phase and at the end of this phase $\mathrm{pH}$ was around 8. The $\mathrm{pH}$ was 7.52 at the start of the anaerobic phase and decreased to 7.3 at the end of this phase due to production of VFA.

Azo dyes are susceptible to biological degradation under sequencing anaerobic and aerobic conditions. The SBR system provided high removal of RR 198. In this removal azo dye acted as a final electron acceptor which 
resulted in color removal under anaerobic conditions in the presence of other carbon source (glucose). However, in the SBR system the aerobic, facultative and anaerobic microbial consortia were present together in the reactor. In this study it was observed that under anaerobic conditions, lower ORP $(<-400 \mathrm{mV})$ values resulted in effective decolorization. The ORP values observed in this study are lower than the values reported in the previous studies (Rau et al., 2002; Field and Brady, 2003; Ong et al., 2008). The aromatic amines produced in the anaerobic phase were degraded in the subsequent aerobic phase. The other factor that affects bacterial decolorization of RR 198 was $\mathrm{pH}$. It was around neutrality. However, in the previous studies the effect of $\mathrm{pH}$ was reported as negligible between $\mathrm{pH}$ values 7-9.5. Lower reductions were obtained when pH below 7 (Panswad et al., 2001; Ong et al, 2005). Therefore, an SBR system with sequencing anaerobic and aerobic phases is beneficial with mixed microbial consortium for removal of RR 198.

\section{Conclusions}

The results presented in this study showed that high decolourisation of Reactive Red $198(>90 \%)$ is possible in a sequencing batch reactor under anaerobic/aerobic conditions. The color removal over $90 \%$ was achieved with an anaerobic phase duration of $10 \mathrm{~h}$. The concentration of RR 198 of 20 and $50 \mathrm{mg} \mathrm{l}^{-1}$ did not show inhibitory effect on the activity of the microorganisms. The COD concentration had also impact on the color removal. The ORP used as a control parameter showed that when ORP was $<-400 \mathrm{mV}$ the RR 198 removal was $>90 \%$. However, when the color removal was about $>80 \%$ ORP was about $<-100 \mathrm{mV}$.

\section{References}

Albuquerque M.G.E., Lopes A.T., Serralheiro M.L., Novais J.M. and Pinheiro H.M. (2005), Biological sulphate reduction and redox mediator effects on azo dye decolourisation in anaerobic-aerobic sequencing batch reactors, Enzyme and Microbial Technology, 36, 790-799.

Amaral F.M., Kato M.T., Florêncio L. and Gavazza S. (2014), Color, organic matter and sulfate removal from textile effluents by anaerobic and aerobic processes, Bioresource Technology, 163, 364-369.

APHA, AWWA, WEF, (2005). Standard methods for the examination of water and wastewater (21th Edition) Washington: APHA, AWWA, WPCF.

Baêta B.E.L., Luna H.J., Sanson A.L., Silva S.Q. and Aquino S.F. (2013), Degradation of a model azo dye in submerged anaerobic membrane bioreactor (SAMBR) operated with powdered activated carbon (PAC), Journal of Environmental Management, 128, 462-470.

Bromley-Challenor K.C.A., Knapp J.S., Zhang Z., Gray N.C.C., Hedheridge M.J. and Evans M.R. (2000), Decolorization of an azo dye by unacclimated activated sludge under anaerobic conditions, Water Research, 34, 4410-4418.

Cirik K. Kitis M. and Cinar O. (2013), The effect of biological sulfate reduction on anaerobic color removal in anaerobicaerobic sequencing batch reactors, Bioprocess and Biosystems Engineering, 36, 579-589.

Dos Santos A.B., Cervantes F.J. and Lier J.B. (2007), Review paper on current technologies for decolourisation of textile wastewaters: Perspectives for anaerobic biotechnology, Bioresource Technology, 98, 2369-2385.

Field J.A. and Brady J. (2003), Riboflavin as a redox mediator accelerating the reduction of azo dye Mordant Yellow 10 by anaerobic granular sludge, Water Science Technology, 48, 187-193

García-Montaño J., Torrades F., García-Hortal J.A., Domènech X. and Peral J. (2006), Combining photo-fenton process with aerobic sequencing batch reactor for commercial hetero-bireactive dye removal, Applied Catalysis B: Environmental, 67, 86-92.

Isik M. and Sponza D.T. (2004), A batch kinetic study on decolorization and inhibition of reactive black 5 and direct brown 2 in an anaerobic mixed culture, Chemosphere, 55, 119-128.

Khosa M.A., Shah S.S. and Feng X. (2013), Micellar enhanced ultrafiltration of organic dyes, Separation Science and Technology, 48, 1315-1323. 
Liu Z.Q., Tan L., Li Y. and Xi D.L. (2013), Decolorization of textile wastewater using modified facultative anaerobic baffled reactor, Advanced Materials Research, 627, 386-389.

Lourenço N.D. Novais J.M. and Pinheiro H.M. (2001), Effect of some operational parameters on textile dye biodegradation in a sequential batch reactor, Journal of Biotechnology, 89, 163-174.

Lourenço N.D., Novais J.M. and Pinheiro H.M. (2006), Kinetic studies of reactive azo dye Decolorization in anaerobic/aerobic sequencing batch reactors, Biotechnology Letters, 28, 733-739.

Ong S.A., Toorisaka E., Hirata M. and Hano T. (2005), Treatment of azo dye orange II in aerobic and anaerobic-SBR systems, Process Biochemistry, 40, 2907-2914.

Ong S.A., Toorisaka E., Hirata M. and Hano T. (2008), Granular actived carbon-biofilm configured sequencing batch reactor treatment of C.I. Acid Orange 7, Dyes and Pigments, 76, 142-146

Panswad T. and Luangdilok W. (2000), Decolorization of reactive dyes with different molecular structures under different environmental conditions, Water Research, 34, 4177-4184.

Panswad T., lamsamer, K., and Anotai J. (2001), Decolorization of azo-reactive dye by polyphosphate and glycogenaccumulatig organisms in an anarobic-aerobic sequencing batch reactors, Bioresource Technology, 76, $151-159$.

Panswad T., Techovanich A. and Anotai J. (2001), Comparison of dye wastewater treatment by normal and anoxic anaerobic/aerobic SBR activated sludge processes, Water Science and Technology, 43, 355-362.

Pasukphun N. and Vinitnantharat S. (2003), Degradation of organic substances and reactive dye in an immobilized-cell sequencing batch reactor operation on simulated textile wastewater, Journal of Environmental Science and Health, 10, 2019-2028.

Patel H. and Vashi R.T. (2013), Comparison of naturally prepared coagulants for removal of COD and color from textile wastewater, Global NEST Journal, 15, 522-528.

Pearce C.I., Lloyd J.R. and Guthrie J.T. (2003), The removal of colour from textile wastewater using whole bacterial cells: A review, Dyes and Pigment, 58, 179-196.

Pinheiro H.M., Touraud E. and Thomas O. (2004), Aromatic amines from azo dye reduction: status review with emphasis on direct UV spectrophotometric detection in textile industry wastewaters, Dyes and Pigments, 61, 121-139.

Rau J., Knackmuss, H.J. and Stolz, A. (2002), Effects of different quinoid redox mediators on the anaerobic reduction of azo dyes by bacteria, Environmental Science Technology, 36, 1497-1504

Razo-Flores E., Luijten M., Donlon B.A., Lettinga G. and Field J.A. (1997), Biodegradation of selected azo dye under methanogenic conditions, Water Science and Technology, 36, 65-72.

Shaw C.B., Carliell C.M. and Wheatley A.D. (2002), Anaerobic/aerobic treatment of coloured textile wastewater using sequencing batch reactor, Water Research, 36, 1993-2001.

Sirianuntapiboon S., Chairattanawan, K. and Jungphungsukpanich, S. (2006), Some properties of a sequencing batch reactors system for removal of vat dyes, Bioresource Technology, 97, 1243-1252.

Talarposhti A.M., Donnelly T. and Anderson G.K. (2001), Colour removal from a simulated dye wastewater using a twophase anaerobic packed bed reactor, Water Research, 35, 425-432.

Van der Zee F.P. and Villaverde S. (2005), Combined anaerobic-aerobic treatment of azo dyes-A short review of bioreactor studies, Water Research, 39, 1425-1440.

Weisburger J.H. (2002), Comments on the history and importance of aromatic and heterocyclic amines in public health, Mutation Research/Fundamental and Molecular Mechanisms of Mutagenesis, 506-507, 9-20.

Wijetunga S., Li X.F. and Jian C. (2010), Effect of organic load on decolourization of textile wastewater containing acid dyes in upflow anaerobic sludge blanket reactor, Journal of Hazardous Materials, 177, 792-798. 